\title{
The influence of the level of definition of functional specifications on the environmental performances of a complex system. EcoCSP approach
}

\section{Nicolas Tchertchian ${ }^{1}$, Dominique Millet ${ }^{1}$, Pierre Alain Yvars $^{2}$}

\author{
'Design \& Ecodesign Methodology' Lab \\ ${ }^{1}$ S U P M E C A - Toulon, Avenue de l’Université - BP 20132 - 83957 La Garde Cedex, France \\ ${ }^{2}$ S U P M E C A - 3, rue Fernand Hainaut, 93407 Saint-Ouen Cedex, France
}

\begin{abstract}
:
The tendency towards a homogenous mode of development modeled on that of Western countries means that sustainable development has become increasingly urgent. It is necessary to thoroughly redefine products and their expected performances in such a way that the consequences are compatible with sustainable development. In the domain of product design, this means that it is no longer sufficient to use assessment tools « after the fact » to check the impact of products whose functional unit was definedprior to production; it is now necessary to rethink the definition of the functional unit itself.

This article aims to present an approach basedon a combination of life cycle analysis methods (LCA) and problem solving by constraint satisfaction (CSP). This original approach makes it possible to vary the design of the different dimensions of the functional units of a complex system and thus to make it easier to identify the best architecture along with the best functional definition of the system.

In this study, the EcoCSP approach is applied to define the functional performances of an ecological passenger ferry.

The complexity of couplings between sub-systems and the sheer number of those sub-systems mean that the designer has to use «intelligent » tools. These simulate a great number of scenarios and help him/her to fine-tune the system and make the right technological choices with regard to the right functional specifications.
\end{abstract}

Keywords: Life cycle assessment; Constraint satisfaction problem;Ecodesign; Complex system; ship design;sustainable development

\section{Introduction}

Industrial growth has affected the conditions of life on earth as witnessed by the increase in ecological problems that threaten future generations. In response to this situation, the concept of sustainable development that began in the 80 's, has gradually become mainstream. Sustainable development calls on all actors involved in the evolution of developed societies to balance the economic social and environmental dimensions of their activity.This means setting a new paradigm where reasonable consumption/production has become essential. In order to reach this objective, products and systems must be designed to be sustainable. Sustainable design is different from Eco design and Design for Environment because it goes beyond the environmental optimization of goods and services (Van Weenen1995): it attempts to incorporate the considerations demanded by the three pillarsof sustainable development, namely social, economic and environmental factors.

Various authors (Daly 1973; Simonis 1985; Williams et al. 1987; Herman et al. 1989; Ayres and Kneese 1990; Freeman 1992) have mentioned the radical nature of the technological transformation that needs to be effected in order to improve the environmental performance of a product or system: they have recommended reducing the proportion of material in the economy using expressions such as X Factor, eco-efficiency, industrial ecology, functional economy, dematerialization, product service-system etc.

Today, traditional Eco design approaches either carry out curative environmental assessments (LCA) (Hauschield 2005), or lead designers towards improved solutions by providing guidelines (Wimmer 2001). Both of these approaches, used in the design of complex systems, most often result in global under-optimizations that are unsuited to the design of complex systems. It thus appears necessary to implement new Eco design practices that are better suited to designing such systems.

A complex system can be defined (Krob 2009), (Cilliers 1998) as a system comprising numerous sub-sets that are interdependent; each of these sub-sets has several possible alternative solutions. In general, complex systems have different ways of functioning with performances that change according to conditions of use. Finally, the 
long-term life cycle of a complex system is not easy to predict during the design phase; this is particularly true for life duration, maintenance, component upgrading and end of life.

Any increasein complexity results in the multiplication of technical solutions and thus of possible alternatives. In such cases, design becomes a long process of negotiation within the design team. This negotiation is generally based on an initial definition of the system's specifications - specifications that arerarely questioned during the design process. In this article, we focus on the necessity for the actors concerned to generate a functional negotiation, that is to say, to select the «right » functions, then the characteristics of the system in order to optimizeits environmental performance.

In the following section of this article we deal with the problem of defining functional units in assessing the life cycle of complex systems. In the third part of the article we give a theoretical introduction to the EcoCSP method; this method combines CSP and LCA in order toidentify the optimal architecture of a system by negotiating the functional unit so that an environmental optimum may emerge. In section 4, the EcoCSP approach is applied in the context of designing a new passenger ferry with hybrid technology. Finally in section 5 we discuss the results and estimate the environmental improvement compared to a system with fixed functionalities. Our conclusion in section 6 summarizes the contributions of this article to a global approach, part of which includes EcoCSP.

\section{The innovative Eco designapproach:reassessing functionalities}

\subsection{Improving environmental performances by reassessing product functions}

As underlined by Lagerstedt (2003), environmental performance generally depends on product functionalities. However, from another point of view, the commercial success of a product depends on the functions it offers to users. Lagerstedt (2003) mentions the balance that must be found between the «environmental cost » and the «functional gain». Few methodological supports exist in the domain of tools/methods for environmental improvement or hirarchization, and amongst those that do exist, even fewerenable early intervention in the design process. Current methods of Eco design such as life cycle analysis and other assessment methods derived from this, such as environmental guidelines and checklists, merely identify the causes of environmental problems in order to redesign the product while keeping its functionalities unchanged; this is in contradiction to strategies of radical environmental improvement (X Factor) that necessitate a complete reassessment of product functionalities. Achieving a higher degree of sustainable development requires finding a balance between acceptable impacts and necessary functions. Luttropp (2005) presents different ways of reaching this balance: he favors reducing environmental impacts while increasing the level of the product's functional performance - a win-win situation that eliminates all unnecessary functions. On the other hand, he is critical of the «green fix » strategy (using new materials while keeping all the functions) that result in short term, temporary optimizations; he also judges inefficient the «linear down » strategy (improving environmental impact by downgrading or eliminating functions).

\subsection{The problem of defining the functional unit in the LCA method.}

Life cycle analysis (LCA) is a method of environmental assessment of a product or service over the whole of its life cycle, that is, from the phase of extracting the raw materials and manufacturing the product until the end of life (discharge, recycling, reuse etc.), including distribution, use and maintenance. The methodological framework of LCA is governed by ISO 14040; this distinguishes 4 phases - defining the objectives and the perimeter of the study, taking the inventory of the life cycle, assessing the impactsof the life cycle and interpreting the results). The phase of defining the objectives and perimeter of the study requires the definition of a functional unit. The functional unit is the « quantified performance of a system of products to be used as the unit of reference in a life cycle analysis» (ISO 14044, 2006). The definition of this functional unit is crucial. Indeed, in cases where the LCA study aims to analyze the potential impacts of different options, it is imperative that all the options assessed fulfill the same function in order to be comparable(Jolliet et al. 2005). Now, by constraining the designer to reason by iso-functionality, the LCA methods and its derivations naturally hinder thinking about products that might have a better balance between environmental cost and functional gain (Luttropp and Lagerstedt2006). In general, the available tools, amongst them LCA, are based on a single criterion: the main function expressed in the form of a functional unit (Lagerstedt 2003). This means that very different products or concepts can be compared.

Consequently, when comparative LCA's are undertaken for these types of products (i.e. that have several functions), it is important to consider the other sub-functions. If these functions are not identified, broken down, specified and/or prioritized in the right way with regard to the objectives and perimeter of the study, it could result in a functional unit that does not reflect reality. As underlined by Reap et al. (2008), these are important questions, for they can downgrade the precision of the reference flows associated with the chosen functional unit and thus decrease confidence in LCA results. 
2.3. State of the art review of environmental assessments (LCA) on systems of transport and vehicles.

In the literature, numerous products and systems have been environmentally assessed using LCA. In order to highlight the problems related to the definition of a functional unit, about thirty LCA studies published by 3 scientific publishers (Springer, Taylor \& Francis, Elsevier) between 2003-2013 as well as a few LCA studies presented in the context of doctoral theses were evaluated in the domain of transport systems.

Each of these LCA studies is characterized by the system (mainly vehicles), the functional unit attributed by the author and the parameters that were modified during the sensitivity test. The results are given in Table 1. This non-exhaustive state of the art on new technologies in the transport sector (especially cars) shows that the functional unit is very often assimilated to a principle function: that of transporting a person or an object from A to $\mathrm{B}$ over a distance of $\mathrm{x}$ thousand kilometers. As stressedin the previous paragraph, and highlighted by Reap et al. (2008), vehicles are complex systems with sub-functions that must be taken into account when two systems are being compared. 
Table1:State of the artreview of LCA studies in the domain of transport.

\begin{tabular}{|c|c|c|c|}
\hline Paper & System & Functional Unit & Variability/Sensitivity \\
\hline $\begin{array}{l}\text { Spielmann, De Haan and } \\
\text { Scholz } 2008\end{array}$ & High-speed underground maglev train & $\begin{array}{l}\text { Average daily mobility of an average Swiss } \\
\text { traveler }\end{array}$ & Not include \\
\hline MacLean and Lave 2003 & A Car: A-Class Mercedes Benz & $1000 \mathrm{~km}$ traveled by the vehicle & Not include \\
\hline Strazza et al. 2010 & $\begin{array}{l}\text { Auxiliary power systems for commercial } \\
\text { vessels }\end{array}$ & $1 \mathrm{kWh}$ of electricity generated & Variations in efficiency \\
\hline $\begin{array}{l}\text { Hussain, Dincer and Li } \\
2007\end{array}$ & $\begin{array}{l}\text { Polymer electrolyte membrane (PEM) fuel } \\
\text { cell automobile }\end{array}$ & lifetime is assumed to be $300,000 \mathrm{~km}$ & Not include \\
\hline Ally and Pryor 2007 & Fuel cell bus & $55,000 \mathrm{~km}$ annually, with a lifetime of 16 years & Fuel cell durability \\
\hline Gao and Winfield 2012 & $\begin{array}{l}6 \text { Cars (Corolla, Prius, Prius Plug-in, Volt, } \\
\text { Leaf, Clarity) }\end{array}$ & Lifetime of 160,000 miles, & Distance between charge \\
\hline Finkbeiner et al. 2006 & Mercedes Benz S-Class Car (S 350) & Driving distance $300000 \mathrm{~km}$ & Sensitivity analyses of car module structure \\
\hline Schweimer and Levin 2000 & $\begin{array}{l}\text { Golf A4, } 1999 \text { model, 4-door: } 1.4 \text { litre } 55 \mathrm{~kW} \\
\text { Petrol and } 1.9 \text { litre } 66 \mathrm{~kW} \text { TDI diesel } \\
\end{array}$ & $\begin{array}{l}\text { The functional unit is a } 150,000 \mathrm{~km} \text { of driving } \\
\text { distance over } 10 \text { years }\end{array}$ & Not include \\
\hline Schmidt et al. 2004 & $\begin{array}{l}\text { European, com-pact-sized, 5-door gasoline } \\
\text { vehicle }\end{array}$ & $\begin{array}{l}\text { Reference scenario with a mileage of } 150,000 \mathrm{~km} \\
\text { over } 12 \text { years }\end{array}$ & $\begin{array}{l}\text { Variation of Weight Reference } 1000 \mathrm{~kg}, 900 \text { and } \\
\text { alternatives }\end{array}$ \\
\hline Lee et al. 2000 & $\begin{array}{l}\text { A typical tractor (model: LT360D) produced } \\
\text { in LG Machinery }\end{array}$ & $\begin{array}{l}\text { The functional unit is one set of a typical tractor } \\
\text { which cultivates about } 92 \text { ha of land for its entire } \\
\text { life span ( } 8 \text { years) }\end{array}$ & Not include \\
\hline $\begin{array}{l}\text { Castro, Remmerxwaal and } \\
\text { Reuter } 2003\end{array}$ & $\begin{array}{l}\text { Generic Compact Class Passenger Vehicles, } \\
\text { the weight is considered to be around } 900 \mathrm{~kg} \\
\text { and its fuel consumption to be } 11.5 \mathrm{~km} / 1\end{array}$ & $\begin{array}{l}\text { The functional unit is a } 200000 \mathrm{~km} \text { of driving } \\
\text { with lifetime of approximately } 14 \text { years }\end{array}$ & Not include \\
\hline $\begin{array}{l}\text { Tharumarajah and Koltun } \\
2007\end{array}$ & $\begin{array}{l}\text { A medium size car with a mass MV }=1300 \\
\mathrm{~kg} \text { and fuel consumption of } \mathrm{K}=8.5 \mathrm{l} \text { per } 100 \\
\mathrm{~km} \text { of driving }\end{array}$ & $\begin{array}{l}\text { The car reaches the end of its life after a driving } \\
\text { distance of } 200,000 \mathrm{~km}\end{array}$ & Variation of Engine Block materials \\
\hline $\begin{array}{l}\text { Takeda, Sugioka and } \\
\text { Shimada } 2008\end{array}$ & $\begin{array}{l}4 \text { different car technologies, Gazoline } \\
\text { Vehicle, Hybrid Electric Vehicle, Electric } \\
\text { Vehicle, Fuel Cell Vehicle }\end{array}$ & A mileage of $100,000 \mathrm{~km}$ over 10 years. & $\begin{array}{l}\text { Different production process of hydrogen in the } \\
\text { process }\end{array}$ \\
\hline Spielmann et al. 2005 & $\begin{array}{l}\text { Supply of regional transport: rail, bus and } \\
\text { private car }\end{array}$ & A seat kilometer & Different level of comfort in train \\
\hline Boureima et al. 2008 & Conventional and alternative passenger car & $\begin{array}{l}\text { The life time driven distance of the vehicles will } \\
\text { range from approximately } 50000 \mathrm{~km} \text { to } 400000 \\
\mathrm{~km}\end{array}$ & A range of life time driven distance is defined \\
\hline $\begin{array}{l}\text { Sweeting and Winfield } \\
2012\end{array}$ & $\begin{array}{l}\text { Light duty vehicles (Batterry electric } \\
\text { vehicles, fuel cell vehicles, Spark ignition } \\
\text { engine vehicles, Compression ignition engine } \\
\text { vehicles) }\end{array}$ & $\begin{array}{l}150,000 \mathrm{~km} \text { for the lifetime distance travelled } \\
\text { with lifetime of } 13 \text { years }\end{array}$ & Different fuel alternatives for each powertrain te \\
\hline Baptista et al. 2011 & A fuel cell hybrid taxi & $\begin{array}{l}\text { Around } 350,000 \text { miles was assumed for the Taxi } \\
\text { lifetime corresponding to an average of around } \\
56,000 \text { miles per year }\end{array}$ & $\begin{array}{l}\text { Range of the number of components and consur } \\
\text { replacements, } 3 \text { electric battery discharging strat } \\
\text { hydrogen } \\
\text { powered vehicles }\end{array}$ \\
\hline Mayyas et al. 2012 & Vehicular body-in-white & 200,000 miles & $\begin{array}{l}\text { Changed independently (no interaction between } \\
\text { parameters): energy embodied, manufacturing er } \\
\text { distance travelled, fuel economy, recycle fractiol }\end{array}$ \\
\hline Zamel and Li 2006 & $\begin{array}{l}\text { Fuel cell vehicles and internal combustion } \\
\text { engine vehicles }\end{array}$ & $300,000 \mathrm{~km}$ & Not include \\
\hline $\begin{array}{l}\text { Bartolozzi, Rizzi and Frey } \\
2010\end{array}$ & hydrogen and electric vehicles & $\begin{array}{l}\text { Deliver goods within an urban area with an } \\
\text { average estimated daily route of } 200 \mathrm{~km}\end{array}$ & $\begin{array}{l}\text { Different hydrogen production scenario; Differe1 } \\
\text { electricity production scenario }\end{array}$ \\
\hline $\begin{array}{l}\text { Wagner, Eckel and } \\
\text { Tzscheutschler } 2006\end{array}$ & $\begin{array}{l}\text { Fuel cell powertrain systems (medium size } \\
\text { passenger car) }\end{array}$ & $\begin{array}{l}\text { A physical lifetime of } 10 \text { years and a total mileage } \\
\text { of } 150,000 \mathrm{~km} \text { in the NEDC }\end{array}$ & Not include \\
\hline Nagatomo et al., 1997 & Shinkansen vehicle & $\begin{array}{l}\text { The electric consumption per } 1 \mathrm{~km} \text { running } \\
\text { (lifetime } 8 \text { Million } \mathrm{km} \text { ) }\end{array}$ & Not include \\
\hline Schwab Castella et al. 2009 & Rail car-bodies for a Korean train & $\begin{array}{l}\text { The functional unit is one car-body for the TTX } \\
\text { train, with a lifetime of } 25 \text { years and used over } \\
7,500,000 \mathrm{~km}\end{array}$ & $\begin{array}{l}\text { Different material scenario: Steel, full composite } \\
\text { composit, Aluminium 10\% recycled and alumini } \\
\text { recycled. Different electricity production scenari }\end{array}$ \\
\hline Horvath 2006 & Freight Transportation & Ton-mile (ton-km) & $\begin{array}{l}\text { \% Empty miles; Vehicle lifetime; vehicle utilizal } \\
\text { Average distance per shipement; etc. }\end{array}$ \\
\hline Nanaki and Koroneos 2012 & Middle size and recent car & $100 \mathrm{~km}$ & Not include \\
\hline $\begin{array}{l}\text { Zackrisson, Avellán and } \\
\text { Orlenius } 2010\end{array}$ & Battery for plugin hybrid & $\begin{array}{l}\text { 10kWh sustaining } 3000 \text { charge cycles at } 80 \% \max \\
\text { discharge }\end{array}$ & $\begin{array}{l}\text { Battery efficiency; electricity production scenari } \\
\text { energy of batteries relationship }\end{array}$ \\
\hline Pehnt 2002 & Fuel Cell system & $1 \mathrm{kWh}$ electric & Not include \\
\hline Mousazadeh et al. 2011 & Solar assist plugin hybrid Tracor & 12000 hours $2.9 \mathrm{~h} /$ day & Not include \\
\hline Ma et al. 2012 & $\begin{array}{l}\text { battery electric vehicles and internal } \\
\text { combustion vehicles }\end{array}$ & Per vehicle km travelled lifetime 15 years & $\begin{array}{l}\text { Vehicle life; Vehicle annual mileage; driving col } \\
\text { drive } \\
\text { cycle and auxiliary loadings }\end{array}$ \\
\hline Querini et al. 2012 & Electric vehicles & Lifetime 10 years $150000 \mathrm{~km}(15000 \mathrm{~km} / \mathrm{y})$ & Not include \\
\hline Laudon and Soriano 2012 & $\begin{array}{l}\text { Electric heavy Vehicles (hybrid and plugin } \\
\text { hybrid) waste collection vehicle and } \\
\text { distribution truck }\end{array}$ & $\begin{array}{l}\text { Waste collection } 300000 \mathrm{~km}(21000 \mathrm{~km} / \mathrm{y}) \text { and } \\
\text { distribution truck } 1000000 \mathrm{~km}(66000 \mathrm{~km} / \mathrm{y})\end{array}$ & $\begin{array}{l}\text { Variation of amount of charge by day; type of el } \\
\text { grid loss }\end{array}$ \\
\hline $\begin{array}{l}\text { Van Mierlo, Maggetto and } \\
\text { Lataire } 2006\end{array}$ & Battery, hybrid, and fuel cell vehicles & $\begin{array}{l}\text { Passenger kilometers (p.km) and ton kilometers } \\
\text { (ton.km) }\end{array}$ & Not include \\
\hline $\begin{array}{l}\text { Koffler and Rohde- } \\
\text { Brandenburger } 2010 \\
\end{array}$ & Internal combustion engine vehicle & Fuel consumption $100 \mathrm{~kg} \times 100 \mathrm{~km}$ (NEDC) & Weight variation of vehicle body structure \\
\hline Subic and Schiavone 2010 & Internal combustion engine vehicle $1500 \mathrm{~kg}$ & A total mileage of $200,000 \mathrm{~km}$ & Driving conditions : drive cycle \\
\hline
\end{tabular}

3 In thirteen studies the variability of functional unit is not taken account. Among the functional modifications 4 suggested, the modification of the driving cycle (annual mileage, vehicle lifetime, use), reduction of the vehicle's 5 mass, the number of battery charges, etc. All these functional modifications are integrated into the process of 6 sensitivity analysis required by the ISO norm. Now, in actual fact, the designer only looks at the extra gains or 7 impacts generated by the modification of one or several parameters; he/she takes no account of the 8 consequences on the whole of the system. These modifications are not completed by a redefinition of the design 9 parameters. Indeed, if we take the example of the reduction of a vehicle's mass, this could potentially call for a 10 different distribution of the masses of the vehicle, and thus a modification of the system's aerodynamic 11 performances that might generate a resizing of the propulsion. 
3. Presentation of the EcoCSP approach

The EcoCSP approach is a further development of the CSP/ LCA approach proposed by (Tchertchian et al. 2013). This approach is based on a combination of 2 methods «Constraint Satisfaction Problem»/Life Cycle Assessment.

\subsection{Definition of a CSP}

A CSP (Constraint Satisfaction Problem) is defined by (Montanary, 1974):

$X=\{x 1, x 2, x 3, \ldots, x n\}$, a set of variables, $n$ being the number of variables of the problem. To keep the generic element, we say that these variables may relate to design, performance or state. Design parameters structure the design and their values distinguish between two design configurations. The instantiation of all the design parameters defines the complete potential design solution. Performance parameters translate the state or the quality of a design alternative and compare it to a reference from the specifications or one related to the state of the art of the company or sector concerned. These characteristics are linked to the translation of a given configuration in physical terms and are generally directly linked to the design parameters.

$\mathrm{D}=\{\mathrm{d} 1, \mathrm{~d} 2, \mathrm{~d} 3, \ldots, \mathrm{dn}\}$, a set of domains. Each domain, associated to a variable, can be discrete or continuous.

$\mathrm{C}=\{\mathrm{c} 1, \mathrm{c} 2, \mathrm{c} 3, \ldots, \mathrm{cp}\}$, a set of constraints, $\mathrm{p}$ being the number of constraints of the problem. The constraints translate how the structuring functions are carried out by the system during the life situation in question. The constraints take the form of explicit relationships between several variables. These relationships impose restrictions on the domains of possible values for the variables of the problem. More precisely, it can be a logical combination of several elementary constraints, among the following:

- Extensive constraints:a constraint in extension describes an explicit and exhaustive list of possible, or on the contrary, impossible combinations - of values ( $m$-tuples) between the $\mathrm{m}$ variables at play within the constraint.

- Intensive constraints: a constraint in intension is an explicit equivalence (or non equivalence) linking two variables to each other (equality or inequality). It brings linear and/or non-linear operators into play.

- Logical constraints: conditional constraints (IF....THEN), conjunction of constraints (AND), disjunction of constraints (OR), obtain logical combinations of constraints. In the case of designing a complex system, logical constraints establish composition relationships among the system's components and define «components » whose state of functioning varies over the life cycle.

Environmental criteria come into the CSP approach as constraints to be satisfied in order to respond to an objective of environmental optimization. Depending on the objectives required by the designer, the algorithm of resolution indicates system architectures and operation modes (if these exist) that respect these constraints. Figure 1 shows the resolution of CSP. 


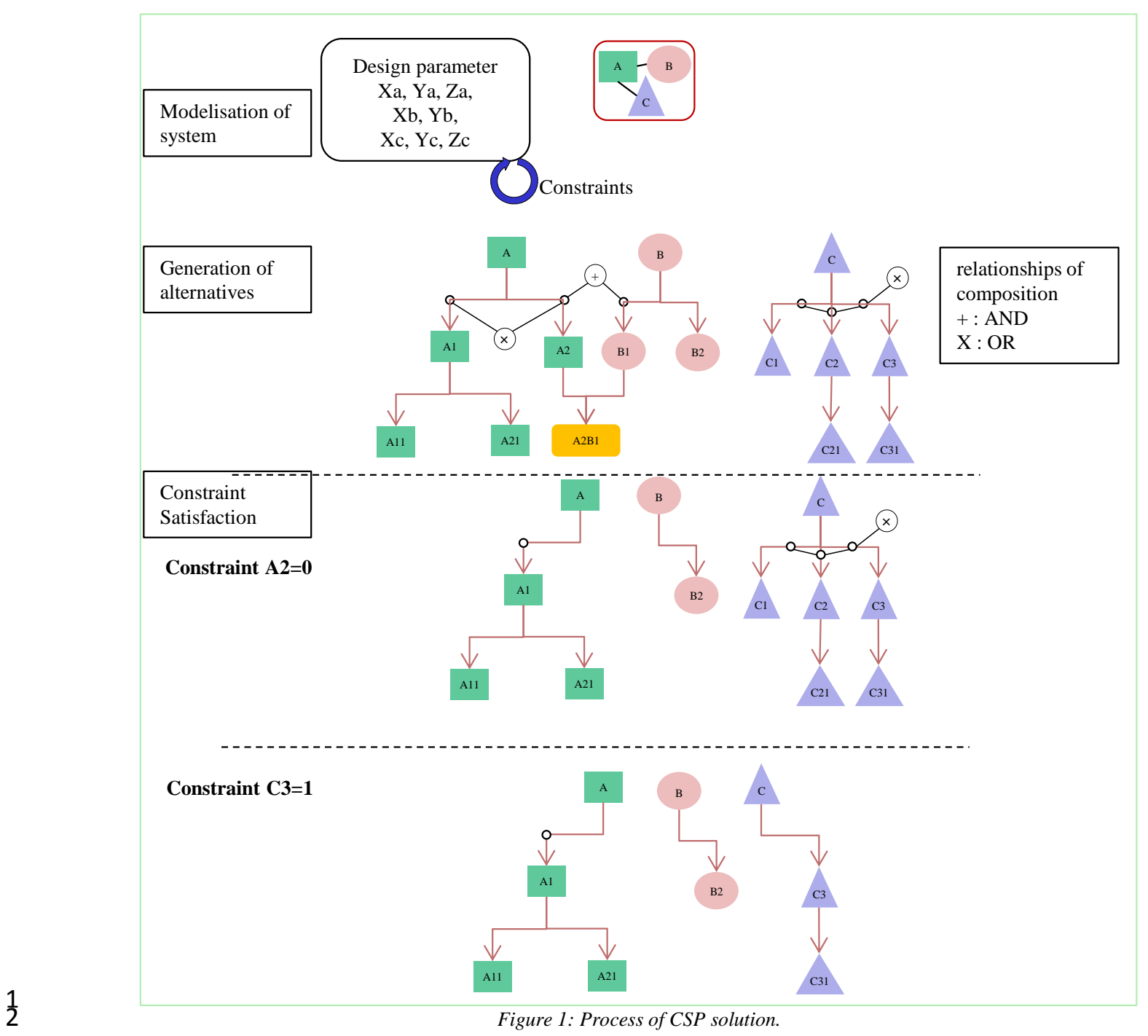

\subsection{CSP resolution}

Resolution by constraint satisfaction results in a complete set of solutions that enable the design team to choose one suited to a design problem according to specific performance variables and constraints. A CSP is typically solved by reducing the domains. The objective of propagating constraints is to replace an initial CSP by an equivalent one which has a more restricted research space. The most basic way of reducing the area for solution is to proceed by trial and error or by dichotomy. A more systematic method is to use filtering techniques which rely on arithmetic of intervals (Moore, 1966) and propagation of constraints (Mackworth, 1977).The most commonly used domain filtering techniques are Arc-Consistency (Mackworth, 1977, Debruyne and Bessiere, 2001) for discrete CSP's, Hull-Consistency (Lhomme, 1993, Benhamou, 1995, Benhamou and Older, 1997) and Box- Consistency (Chiriaev and Walster, 1997, Benhamou et al., 1999) for discrete and continuous CSP's. As Chenouard (2007) points out, using CSP in preliminary design has the advantage of great flexibility for expressing knowledge and modifying models; it resolves generic problems. This is a sought after characteristic in design, for it expresses knowledge without defining how it should be dealt with. CSP makes it easier to manipulate and reuse such knowledge.

\subsection{The EcoCSP approach : a development of the CSP/ LCA approach}

The methodology of life cycle analysis uses a normalized functional unit $\left(\mathrm{UF}_{\mathrm{n}}\right)$,to facilitate comparisons among systems that show unequal performances.

Our state of the art review and the compilation of Reap et al.(2008)of the main problems posed by LCA, show that defining a functional unit is not sufficient for the radical improvement of the environmental performances of a complex system. 


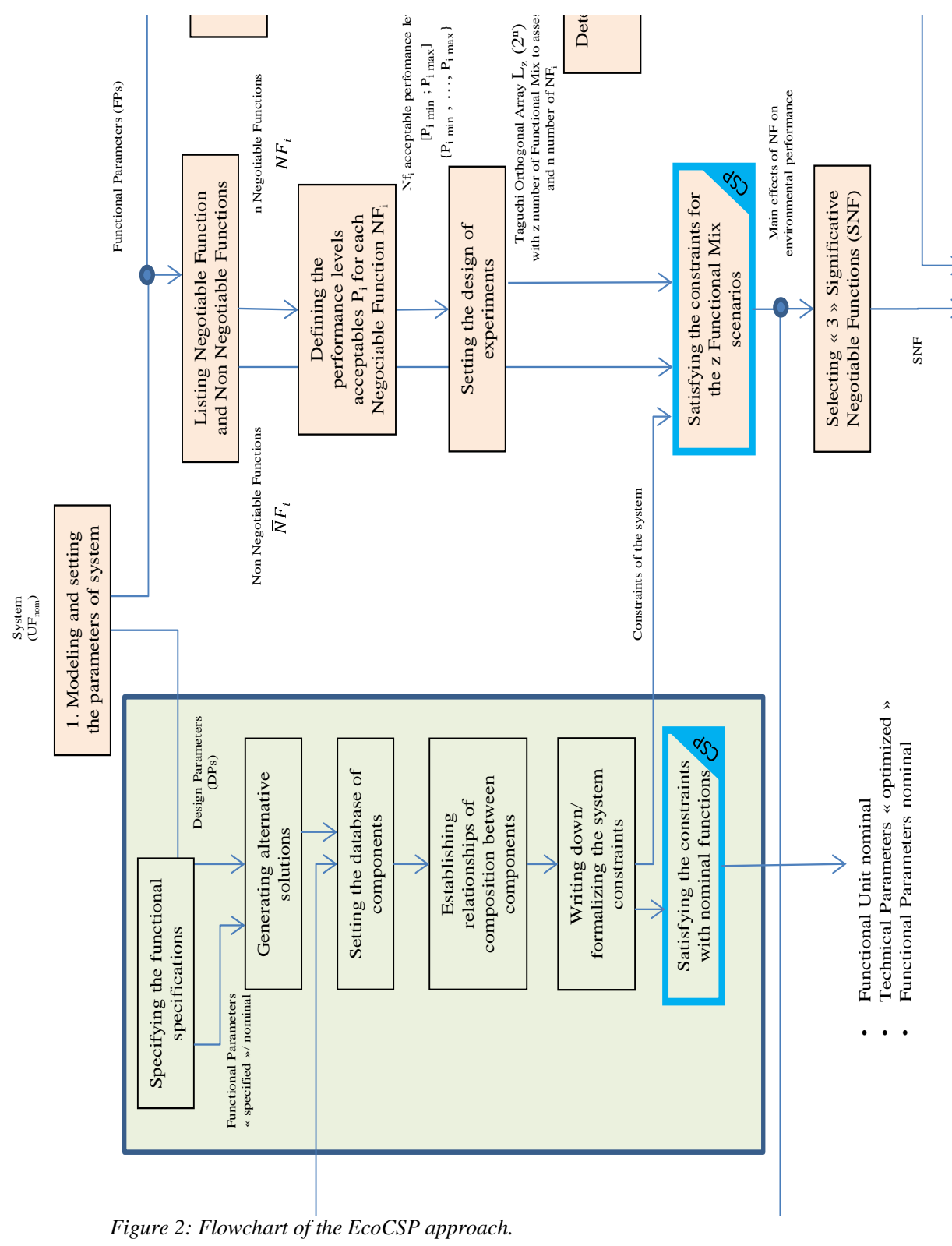

The works of Tchertchian, Yvars and Millet (2013) demonstrated the relevance of an approach combining Constraint Satisfaction Problem solving approach (CSP) and Life Cycle Analysis method to define the best architecture and operation modes of a complex system with respect of environmental constraints. This fruitful research pointed to a way forward. Indeed, the CSP approach allows us to modelise functional requirements as constraints; by exploring these as such, it is then possible to simulate the various architectural alternatives of a complex system while at the same time varying the specifications of that system. We have called this approach EcoCSP.

The general framwork of the EcoCSP approach, represented by a flowchart Figure 2, contains a phase of predefinition of the functional specifications of the system, in which are listed the Negotiable Functions (NF), these areflexible functions in the specification of the " Performance level " expected by the system, and the Non Negotiable Functions $(\mathrm{N} \overline{\mathrm{F}})$, these are functions whose performances are specified from the beginning(ex: functionsrelated withsecurity).

$\mathrm{NF}_{\mathrm{i}} \in\left[\mathrm{P}_{\text {imin }}, \mathrm{P}_{\mathrm{imax}}\right]$, where $\mathrm{P}_{\text {imin }}$ is the minimum level of performance of the function $\mathrm{i}$ and $\mathrm{P}_{\mathrm{i} \text { max }}$ the maximum level of performance.

17 In parallel with the definition of overall performance of the system, the design team defines the range of variation of the Functional Unit (FU). The functional unit defines the quantification of performance 
the environmental burden of the system archuitecture. The globally optimized performance of the system $\left(\mathrm{FU}_{\mathrm{GO}}\right)$ may vary in the domain $\left[\mathrm{P}_{\mathrm{s} \min }, \mathrm{P}_{\mathrm{s} \max }\right]$.

Significant Negociable Function (SNF) which variation of the performance level led to a significant fluctuation of the environmental impact of the system is identified through design of experiments via Taguchi orthogonal array $\mathrm{L}_{\mathrm{z}}$ (Taguchi, Elsayed and Hsiang, 1989). $\mathrm{L}_{\mathrm{z}}$ is an array where $\mathrm{z}$ is the number of simulations required to represent all the effect of NF on environmental criteria.

A design of experiments (DoE) is an efficient way to identify the contribution of each function to the environmental impact. It reduces the number of trials (CSP simulations). Without DoE the number of simulations required to test all functional mixes is $\mathrm{m}^{\mathrm{n}}$ with $\mathrm{n}$ the number of functions and $\mathrm{m}$ the number of performance level for each function.

In this first methodological proposal, the functions are not supposed to interact among themselves and each of them have $m=2$ levels. Each function $\mathrm{NF}_{\mathrm{i}}$ whose performance $\mathrm{P}_{\mathrm{i}}$ is in the domain $\left[\mathrm{P}_{\mathrm{i} \text { min }}, \mathrm{P}_{\mathrm{i} \text { max }}\right]$ the two levels are the upper $\mathrm{P}_{\mathrm{i} \text { max }}$ and lower $\mathrm{P}_{\mathrm{i} \text { min }}$ bounds; for functions $\mathrm{NF}_{\mathrm{i}}$ whose performance is in discrete domain $\left\{\mathrm{P}_{\mathrm{i} 1}, \ldots\right.$, $\left.\mathrm{P}_{\mathrm{ik}}\right\}$ the two levels are the minimum and maximum values.

For example, a functional mix composed of $\mathrm{n}=7 \mathrm{NF}$ and with $\mathrm{m}=2$ performance levels would require $2^{7}$ trials to test all variants of functional mix. The appropriate Taguchi orthogonal arrayis L8 $\left(2^{7}\right)$, reducing the number of CSP simulations toz $=8$ instead of 128 .

Each variant of the functional mix is characterized by a line in DoE (cf. Table2).The results are used to draw the graph of main effect on the average of Environmental Impact (see Figure 3), i.e the effect of each $\mathrm{NF}_{\mathrm{i}}$ on environmental performance.

In Figure 3, for example, the transition from performance level $P_{1 \text { min }}$ to $P_{1 \max }$ of function F1causes a significant change in the average environmental impact $\mathrm{EI}_{\mathrm{Avg}}$, the function $\mathrm{NF} 1$ is a significant negotiable function. The three most "significant" NF are retained in the next step to specify their optimal performance level.

Table2 : Taguchi Orthogonal Array $L_{z}\left(2^{n}\right)$.

\begin{tabular}{|l|l|l|l|l|l|}
\hline Functional Mix & $\mathrm{F}_{1}$ & $\mathrm{~F}_{2}$ & $\mathrm{~F}_{3}$ & $\ldots$ & $\mathrm{F}_{\mathrm{n}}$ \\
\hline 1 & $\mathrm{P}_{1_{\max }}$ & $\mathrm{P}_{2 \max }$ & $\mathrm{P}_{3 \min }$ & & $\mathrm{P}_{\mathrm{nmin}}$ \\
\hline 2 & $\mathrm{P}_{1 \max }$ & $\mathrm{P}_{2 \min }$ & $\mathrm{P}_{3 \max }$ & & $\mathrm{P}_{\mathrm{n} \min }$ \\
\hline & & & & & \\
\hline $\mathrm{Z}$ & $\mathrm{P}_{1 \min }$ & $\mathrm{P}_{2 \min }$ & $\mathrm{P}_{3 \max }$ & & $\mathrm{P}_{\mathrm{nmax}}$ \\
\hline
\end{tabular}

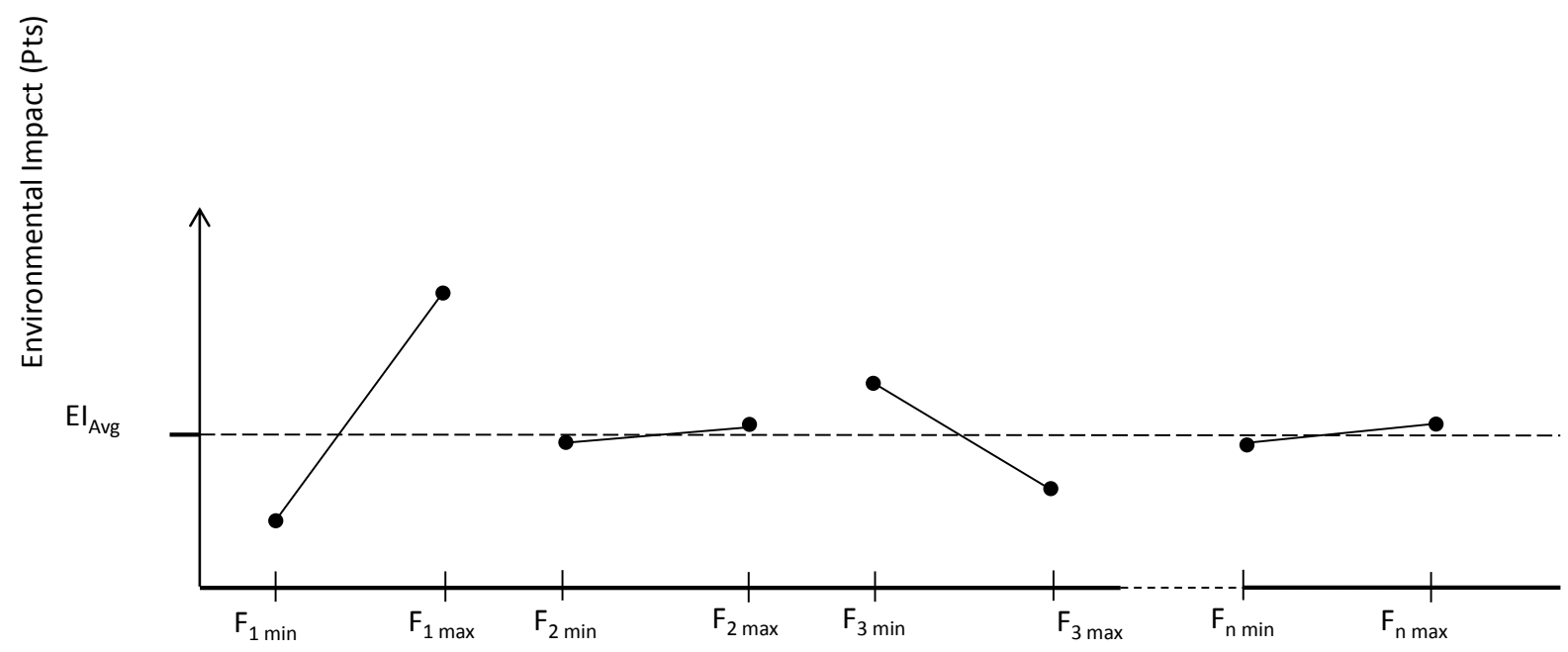

Figure 3 : Graph of Main effect on Environmental Impact of $N F_{i}$.

While the previous approach deals with a functional unit normalised $\left(\mathrm{FU}_{\mathrm{n}}\right)$ and functional performance defined $\left(P_{i n}\right)$ according to system specifications defined at the beginning of design process; the EcoCSP approach allows to model the three significant Negotiable Functions as constraints that operate on domains of 
performance: $\left[\mathrm{P}_{\mathrm{i} \text { min }}, \mathrm{P}_{\mathrm{i} \text { max }}\right]$. Similarly, the functional unit $\mathrm{FU}_{\mathrm{GO}}$ is defined as a constraint in domain $\left[\mathrm{P}_{\mathrm{s} \text { min }}, \mathrm{P}_{\mathrm{s} \text { max }}\right]$. A limited variation in the level of performance of $\mathrm{FU}_{\mathrm{GO}}$ compared to the baseline performance of the $\mathrm{FU}_{\mathrm{n}}$ allows a radical improvement in environmental performance system.

The optimal solution is generated by constraint satisfaction (CSP).Design parameters defining technological choicesfor each subsystem (eg motor sizing), the way of components operate according to the use phase sequences (eg componant activate or not) and the performance level of 3 Functions Negotiable are specified by propagating the constraints.

A CSP solver is used to instantiate the design variables and the performance $P_{i}$ of Negociable Functionsthat minimize the performance variables based on environmental criteria. The constraint solver used is ILOG Solver, developed by IBM. ILOG Solver is a C ++ library. In the flowchart, the solver is involved in 3activity box labelled CSP to satisfy the constraints; generating technological choices, operation modes of components and the performance level of 3 Negotiable Functions.

Finally, we propose an aera of improvement to reduce the impact caused by overproduction of a non-suitable components (oversizing, non-mature technology, etc.) towards the Negotiable Functions performed. Reducing the performance level of the functions of the system creates a need for appropriately sized components to meet performance adapted downwards or upwards. The number of components constituing such databases are not exhaustive, they depend on their availability on the market. Extending the database of components to meet the appropriate performance level should achieve additional environmental benefits. This observation leads to imagine (re) design specific component to achieve the optimal performance level.

EcoCSP allows judgments and choices to be made about functions on the basis of those functions that are deemed negotiable; the approach makes it possible to vary the system's performance in order to reduce environmental impacts.

4. Case Study : designing an eco compatible hybrid passenger ferry

4.1. Simplified modelisation for a complex system - a maritime ferry

The system under study is a maritime passenger ferry that crosses the bay of Toulon. The ferry to be redesigned is equipped with an aluminum hull, two diesel motors and an electric generator to power the auxiliaries.The ferry can transport 100 passengers. The Toulon ferry runs three lines 7 days a week over 300 days per year. Each ferry makes 24 bay crossings daily. The ferry has a lifetime of 20 years. The diesel motors are replaced approximately every 12500 hours (or about $500000 \mathrm{~km}$ ).

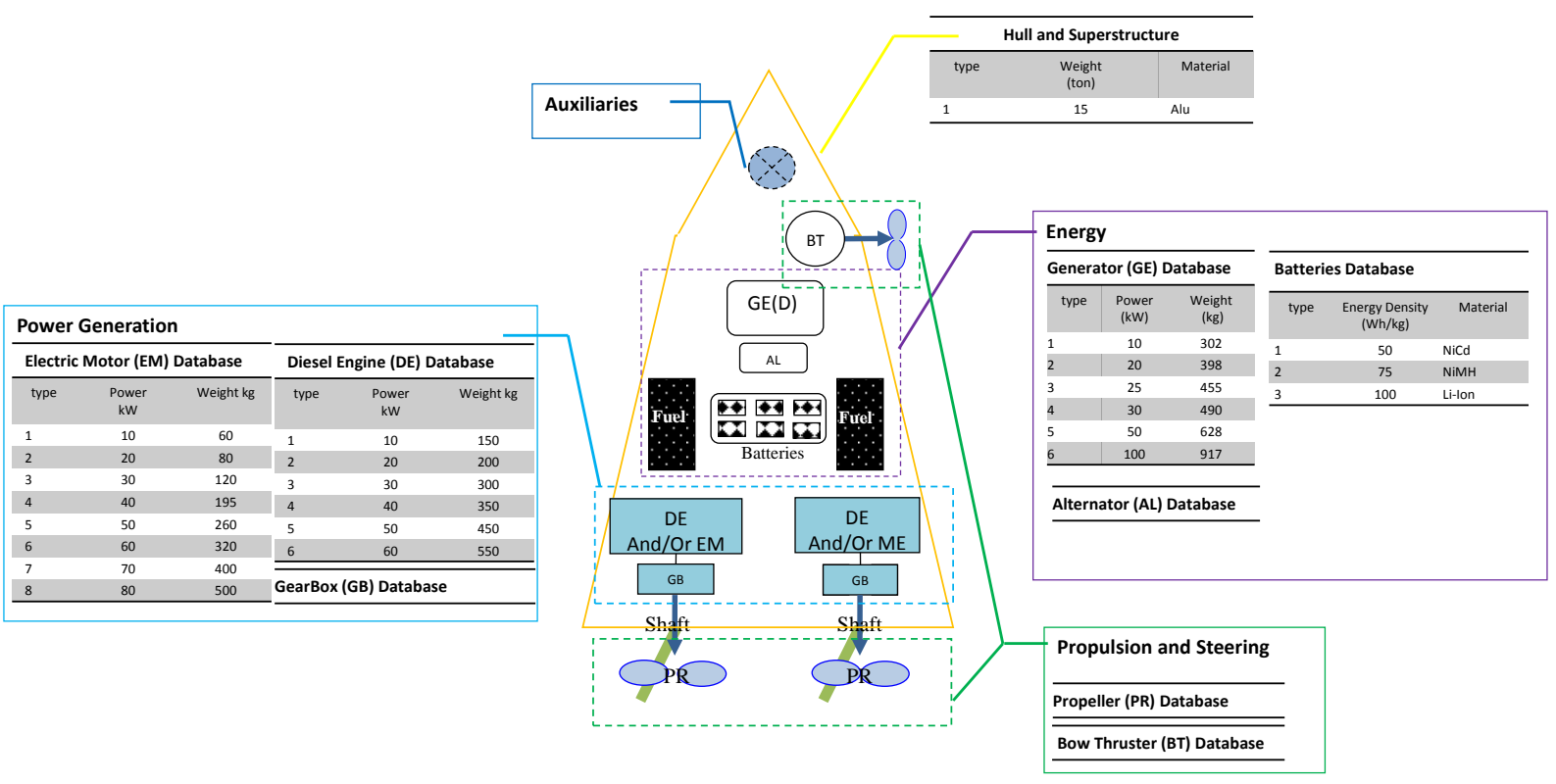


The design project aims to define the architecture and the state of the systems for each sequence of the use cycle according to pre-established conditions of use and assessment criteria (performance variables, environmental, technical and economic criteria respectively). In the case of intercity passenger transport, ship performances are strongly related to conditions of use.

For practical reasons, in this article we have deliberately simplified the system. The passenger ferry is thus broken down into 5 main sub-sets (shown in Figure 4): Hull \& Superstructure, Power Generation, Propulsion andSteering, Energy and Auxiliaries.The main relationships governing the system are shown in the appendices.

\subsection{Defining negotiable functional parameters}

To simplify the problem, we identified 6 Negotiable Functions: maximum cruise speed, maximum passenger capacity, number of daily trips, thermal insulation, air conditioning system and the number of charging / day.

In the classical approach the performance of Negotiable Functions are defined in the specifications, each function is caracterised by a nominal performance level $P_{i \text { nom }}$ (Table3). The functional unit chosen to compare the various systems and functional scenarios is the number of passengers transported per day. The performance corresponding to the nominal Functional Unit $\left(\mathrm{FU}_{\mathrm{n}}\right)$ is 2400 passengers transported a day.

Table3 shows for each Negotiable Functions the acceptable performance level ; eg the performance for NF1 "maximum speed" is :

$$
\mathrm{P}_{1} \in\left[\mathrm{P}_{1 \min }, \mathrm{P}_{1 \mathrm{max}}\right]=[11.5,12] .
$$

Table3 : Definition of nominal performence Pi nom and performance level $\left[P_{i \min }, P_{i \max }\right]$ of $N F_{i}$.

\begin{tabular}{|c|c|c|c|c|c|c|c|}
\hline & \multicolumn{7}{|c|}{ Parameters } \\
\hline Level & $\begin{array}{l}\text { P1: Maximal } \\
\text { Speed }\end{array}$ & $\begin{array}{l}\text { P2: Number of } \\
\text { passengers }\end{array}$ & $\begin{array}{l}\text { P3: Number } \\
\text { of missions }\end{array}$ & P4: isolation & $\begin{array}{l}\text { P5: } \\
\text { Climatisation }\end{array}$ & $\begin{array}{l}\text { P6: Nombre } \\
\text { de charges }\end{array}$ & $\begin{array}{l}\text { Ps : Unité } \\
\text { fonctionnelle }\end{array}$ \\
\hline$P_{\text {i nom }}$ & 12 & 100 & 24 & 1 (insulation) & $1(\mathrm{AC})$ & 1 & 2400 \\
\hline$P_{\text {imin }}$ & 11.5 & 97 & 23 & 0 (no insulation) & 0 (No AC) & 1 & 2231 \\
\hline$P_{\text {imax }}$ & 12 & 100 & 24 & 1 & 1 & 12 & 2400 \\
\hline
\end{tabular}

4.3. Defining significant negotiable functional parameters

They are $2^{6}$ possible functional mix for 6 Negotiable Functions with two performance levels. In order to reduce the number of CSP simulation, the appropriate Taguchi orthogonal array is $\mathrm{L}_{8}\left(2^{6}\right)$ is implemented Table4, representing the main effects of each $\mathrm{NF}$ on the environmental impact.

Table4 : Design of Experiment - Taguchi orthogonal array $L_{8}\left(2^{6}\right)$.

\begin{tabular}{|l|c|c|c|c|c|c|}
\hline $\begin{array}{l}\text { Functional Mix } \\
\text { (FM) }\end{array}$ & $\begin{array}{l}\text { Performance } \\
\text { level forNF1 }\end{array}$ & $\begin{array}{l}\text { Performance } \\
\text { level for NF2 }\end{array}$ & $\begin{array}{l}\text { Performance } \\
\text { level for NF3 }\end{array}$ & $\begin{array}{l}\text { Performance } \\
\text { level for NF4 }\end{array}$ & $\begin{array}{l}\text { Performance } \\
\text { level for NF5 }\end{array}$ & $\begin{array}{l}\text { Performance } \\
\text { level for NF6 }\end{array}$ \\
\hline FM0 & 12 & 100 & 24 & 0 & 0 & 1 \\
\hline FM1 & 12 & 100 & 24 & 1 & 0 & 1 \\
\hline FM2 & 12 & 97 & 23 & 0 & 1 & 12 \\
\hline FM3 & 12 & 97 & 23 & 1 & 1 & 1 \\
\hline FM4 & 11.5 & 100 & 23 & 1 & 0 & 1 \\
\hline FM5 & 11.5 & 100 & 23 & 0 & 1 & 12 \\
\hline FM6 & 11.5 & 97 & 24 & 1 & & 0 \\
\hline FM7 & 11.5 & 97 & 24 & & 12 \\
\hline
\end{tabular}

The Functional Mix 0 (FM0) is the nominal functional mix (maximum speed 12 knots, 100 passengers per day, 24 missions daily, no insulation and air conditioning system, 1 charge per day).

For each mix, the CSP model is solved using ILOG solver generating architectures and operation modes minimizing environmental impact with Eco Indicator 99 (EI 99) scores.

For each Functional mix $\mathrm{FM}_{\mathrm{j}}$, Table5shows the main elements of Architecures $\mathrm{A}_{\mathrm{j}}$ (of the simplified model) selected from the component libraries.

The function «objective» is to minimize the environmental impact over the life cycle (Raw Materials + Manufacturing phase, Use phase and Maintenance phase, the End of Life phase is not included). 
The diagram (Figure 5) shows the distribution of impacts over the three life cycle phases that are assessed. The predominant phase is the Use phase with $87 \%$ of impacts, then the Maintenance phase with $8 \%$ and the Raw Materials +Manufacturing phase with $5 \%$.

The eight Functional Mix scenarios described above are assessed environmentally using the indicator of a single EI99 score in order to make the results clearer. It is understood that a multicriteria assessment is recommended in order that the study be robust. We therefore provide a summary with the results of the multicriteria assessment below in annex.

Table5 : Specifications of main elements of the system.

\begin{tabular}{|c|c|c|c|c|c|c|c|c|c|}
\hline & \multicolumn{8}{|c|}{ Architectures } \\
\hline & & $\begin{array}{c}\text { Functional Mix } \\
0\end{array}$ & \begin{tabular}{|c|} 
Functional Mix \\
1
\end{tabular} & \begin{tabular}{|c|} 
Functional Mix \\
2
\end{tabular} & \begin{tabular}{|c} 
Functional Mix \\
3
\end{tabular} & $\begin{array}{c}\text { Functional Mix } \\
4\end{array}$ & $\begin{array}{c}\text { Functional Mix } \\
5 \\
\end{array}$ & $\begin{array}{c}\text { Functional Mix } \\
6\end{array}$ & $\begin{array}{c}\text { Functional Mix } \\
7\end{array}$ \\
\hline \multirow{2}{*}{ Engine } & Power & $80000 \mathrm{~W}$ & $80000 \mathrm{~W}$ & $70000 \mathrm{~W}$ & $80000 \mathrm{~W}$ & $70000 \mathrm{~W}$ & $70000 \mathrm{~W}$ & $70000 \mathrm{~W}$ & $70000 \mathrm{~W}$ \\
\hline & Weight & $800 \mathrm{Kg}$ & $800 \mathrm{Kg}$ & $750 \mathrm{Kg}$ & $800 \mathrm{Kg}$ & $750 \mathrm{Kg}$ & $750 \mathrm{Kg}$ & $750 \mathrm{Kg}$ & $750 \mathrm{Kg}$ \\
\hline \multirow{2}{*}{ Motor } & Power & $24000 \mathrm{~W}$ & $24000 \mathrm{~W}$ & $22000 \mathrm{~W}$ & $24000 \mathrm{~W}$ & $24000 \mathrm{~W}$ & $24000 \mathrm{~W}$ & $22000 \mathrm{~W}$ & $24000 \mathrm{~W}$ \\
\hline & Weight & $94 \mathrm{Kg}$ & $94 \mathrm{Kg}$ & $85 \mathrm{Kg}$ & $82 \mathrm{Kg}$ & $94 \mathrm{Kg}$ & $94 \mathrm{Kg}$ & $70 \mathrm{Kg}$ & $94 \mathrm{Kg}$ \\
\hline \multirow{2}{*}{ Generator } & Power & 10000 & 10000 & 10000 & 10000 & 10000 & 10000 & 10000 & 10000 \\
\hline & Weight & 200 & 200 & 200 & 200 & 250 & 250 & 250 & 250 \\
\hline \multirow{3}{*}{ Batteries } & $\begin{array}{l}\text { Energy mission (Winter/ } \\
\text { Summer) }\end{array}$ & $15 \mathrm{kWh} / 12,4$ & $13,7 \mathrm{kWh} / 17,7$ & $14,6 \mathrm{kWh} / 11,9$ & $13,7 \mathrm{kWh} / 17,7$ & $15,3 \mathrm{Wh} / 18,0$ & $14,0 \mathrm{Wh} / 12,6$ & $14,8 \mathrm{Wh} / 17,5$ & $14,0 \mathrm{Wh} / 12,6$ \\
\hline & Weight & $501 \mathrm{Kg}$ & $53 \mathrm{Kg}$ & $42 \mathrm{Kg}$ & $565 \mathrm{Kg}$ & $577 \mathrm{Kg}$ & $40 \mathrm{Kg}$ & $53 \mathrm{Kg}$ & $464 \mathrm{Kg}$ \\
\hline & Energy Density & $50 \mathrm{Wh} / \mathrm{Kg}$ & $50 \mathrm{Wh} / \mathrm{Kg}$ & $50 \mathrm{Wh} / \mathrm{Kg}$ & $50 \mathrm{Wh} / \mathrm{Kg}$ & $50 \mathrm{Wh} / \mathrm{Kg}$ & $50 \mathrm{Wh} / \mathrm{Kg}$ & $50 \mathrm{Wh} / \mathrm{Kg}$ & $50 \mathrm{Wh} / \mathrm{Kg}$ \\
\hline Hull & Weight & $15000 \mathrm{Kg}$ & $15000 \mathrm{Kg}$ & $15000 \mathrm{Kg}$ & $15000 \mathrm{Kg}$ & $15000 \mathrm{Kg}$ & $15000 \mathrm{Kg}$ & $15000 \mathrm{Kg}$ & $15000 \mathrm{Kg}$ \\
\hline \multirow{4}{*}{ Ship } & Weight & $27539 \mathrm{~kg}$ & $27648 \mathrm{Kg}$ & $25504 \mathrm{Kg}$ & $27769 \mathrm{Kg}$ & 27587 Pts & $27520 \mathrm{Kg}$ & $25526 \mathrm{Kg}$ & $27462 \mathrm{Kg}$ \\
\hline & $\begin{array}{l}\text { Impact of Use phase / } \\
\text { Mission }\end{array}$ & 2,03 Pts & $1,82 \mathrm{Pts}$ & 1,79 Pts & 2,04 Pts & $1,82 \mathrm{Pts}$ & 1,87 Pts & 1,67 Pts & $1,81 \mathrm{Pts}$ \\
\hline & $\begin{array}{l}\text { Impact of Manufacturing } \\
\text { Phase }\end{array}$ & $16325 \mathrm{Pts}$ & $13901 \mathrm{Pts}$ & $13562 \mathrm{Pts}$ & $16670 \mathrm{Pts}$ & $16690 \mathrm{Pts}$ & $13789 \mathrm{Pts}$ & $13848 \mathrm{Pts}$ & $16079 \mathrm{Pts}$ \\
\hline & Impact of Maintenance & $27134 \mathrm{Pts}$ & $31250 \mathrm{Pts}$ & 24403 Pts & $30244 \mathrm{Pts}$ & $30804 \mathrm{Pts}$ & $32177 \mathrm{Pts}$ & $30839 \mathrm{Pts}$ & $25134 \mathrm{Pts}$ \\
\hline
\end{tabular}

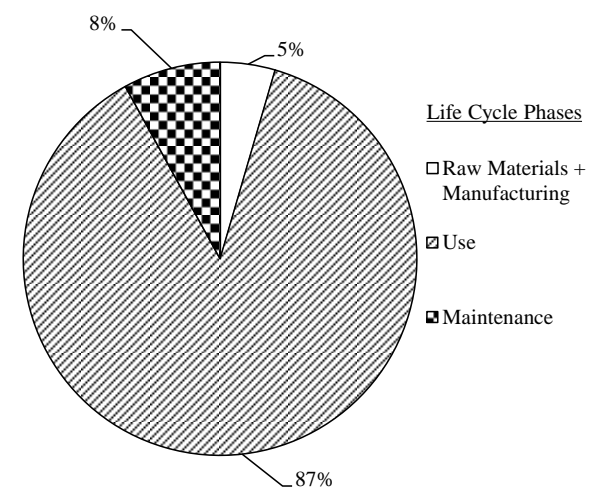

Figure 5 : Average distribution of impacts on life cycle phases.

Table6 : Life Cycle Assessment of Architecture $A_{j}$.

\begin{tabular}{|l|l|l|l|l|l|}
\hline $\begin{array}{l}\text { Functional Mix } \\
(\text { FM })\end{array}$ & $\begin{array}{l}\text { Raw Material + } \\
\text { Manufacturing }\end{array}$ & \multicolumn{1}{|c|}{ Use } & Maintenance & Life Cycle & $\begin{array}{c}\text { Performance } \\
\text { level PSforFU }\end{array}$ \\
\hline FM 0 & 16325 & 318077 & 27134 & 361536 & 2400 \\
\hline FM 1 & 13901 & 331917 & 31250 & 377068 & 2231 \\
\hline FM 2 & 13562 & 259115 & 24403 & 297080 & 2231 \\
\hline FM 3 & 16670 & 296337 & 30244 & 343251 & 2400 \\
\hline FM 4 & 16690 & 268935 & 30804 & 316428 & 2400 \\
\hline FM 5 & 13789 & 269761 & 32177 & 315727 & 2231 \\
\hline FM 6 & 13848 & 270843 & 30839 & 315530 & 2231 \\
\hline FM 7 & 16079 & 285645 & 25134 & 326858 & 2400 \\
\hline Average Impact & 15108 & 287579 & 27936 & 330623 & \\
\hline
\end{tabular}

Table7 : Impact of architectures for functional mix with Design of Experiment $L_{8}\left(2^{6}\right)$. 


\begin{tabular}{|c|c|c|c|c|c|c|c|c|}
\hline Functional Mix & \begin{tabular}{|c|} 
Raw \\
Materials/ \\
Manufacture \\
El $99(\mathrm{Pt})$
\end{tabular} & $\begin{array}{c}\text { Gains (-) or } \\
\text { losses (+)/ FM0 } \\
\text { (\%) }\end{array}$ & $\begin{array}{l}\text { Use } \\
\text { El } 99(\mathrm{Pt})\end{array}$ & $\begin{array}{c}\text { Gains (-) or } \\
\text { losses (+)/FM0 } \\
\text { (\%) }\end{array}$ & $\begin{array}{c}\text { Maintenance } \\
\text { El } 99(\mathrm{Pt})\end{array}$ & $\begin{array}{c}\text { Gains (-) or } \\
\text { losses (+)/ FMo } \\
\text { (\%) }\end{array}$ & $\begin{array}{l}\text { Total } \\
\text { El } 99(\mathrm{Pt})\end{array}$ & $\begin{array}{c}\text { Gains (-) or } \\
\text { losses (+)/ FMO } \\
\text { (\%) }\end{array}$ \\
\hline FM0 & 16325 & & 318077 & & 27134 & & 361536 & \\
\hline FM1 & 13901 & $-14,9$ & 331917 & 4,4 & 31250 & 15,2 & 377067 & 4,3 \\
\hline FM2 & 13562 & $-16,9$ & 259115 & $-18,5$ & 24403 & $-10,1$ & 297080 & $-17,8$ \\
\hline FM3 & 16670 & 2,1 & 296337 & $-6,8$ & 30244 & 11,5 & 343251 & $-5,1$ \\
\hline FM4 & 16690 & 2,2 & 268935 & $-15,4$ & 30804 & 13,5 & 316428 & $-12,5$ \\
\hline FM5 & 13789 & $-15,5$ & 269761 & $-15,2$ & 23685 & $-12,7$ & 307235 & $-15,0$ \\
\hline FM6 & 13848 & $-15,2$ & 270843 & $-14,8$ & 30839 & 13,7 & 315529 & $-12,7$ \\
\hline FM7 & 16079 & $-1,5$ & 285645 & $-10,2$ & 25134 & $-7,4$ & 326857 & $-9,6$ \\
\hline
\end{tabular}

- $\quad$ Assessment of the Raw Materials + Manufacturing phase

Each architecture generated by functional mix described by design of experiment (Table4) is environmentally assessed (Table7). The graph of main effects (Figure 6) illustrates the influence of Negotiable Functions on the Raw materials and Manufacturing impact. Functions from 1 to 5 have little impact on Raw materials and Manufacturing phase. The number of battery charge (NF6), explains largely environmental gains measured for Functional Mix scenarios 1, 2, 5 and 6. In fact, recharging batteries more often, the amount of energy to be stored becomes less important and the need for batteries is less. Batteries, with the superstructure of the ship, are the main contributors to the impacts in Raw materials and Manufacturing phase.

- Assessment of the Use phase

The use phase represents over $85 \%$ of the impacts generated by the passenger ferry. Moreover, as shown by the various assessments of scenarios 1 to 7 (Table7), the environmental impact of use is sensitive to the variation of negotiable functionalities.

The best functional mixes allow more than $10 \%$ gains.

The performance level of NFs leads to a variation of the average environmental impact generated by the eight functional mix scenarios of the DoE of :

- $\quad 4.5 \%$ for $\mathrm{NF}_{3}$,

- $3.3 \%$ for $\mathrm{NF}_{1}$,

- $2.7 \%$ forNF $\mathrm{N}_{2}$,

- $2.5 \%$ for $\mathrm{NF}_{4}$,

- $1.3 \%$ for $\mathrm{NF}_{6}$,

- $\quad$ and $0.9 \%$ for $\mathrm{NF}_{5}$.

The analysis of different scenarios associated with a functional mix explains in part the impacts resulting of the use phase. Reducing the maximum speed or the number of missions per day, reduces the fuel consumption.

The increase of the number of batteries chargeleads to reducethe mass of batteries and thus reducing the need of propelling poweras system presents less drag. In the same way reducing passenger capacity per mission also reduces the propulsive power. The combination of air conditioning and insulation of system is more difficult to predict, better insulation improves thermal efficiency but weighed down the system increasing fuel consumption while air conditioning increases the energy demand of the system.

- Assessment of the maintenance phase

The ferry undergoes maintenance throughout its entire life cycle: motors are changed (lifetime of 12500 running hours) and batteries are charged and uncharged (600 cycles for this study). Initially, 5 motors are used over the ship's life time involving 4 changes of motor. For a single charge/uncharge cycle per day, batteries must be replaced 9 times. The batteries are the components generating the highest impact. The number of missions per day leads to a variation of $5 \%$ of the average environmental impact of maintenance phase. The use of the system is due to the number of mission it performs by day, which generates wear of these main components.

- Global assessment of scenarios

The overall impact (Raw materials, Use and maintenance) of the various scenarios associated with a Functional Mix of DoE follows the trend drawn by the use phase, in fact $87 \%$ of the environmental impacts caused by the 
use phase.The three significant functions are determined by the functions generating the greatest variation on the overall impact, they are characterized by observation on the graph of main effects (Figure 6). The performance level of NF1, NF2 and NF3 leads, respectively, to a variation of $3.3 \%, 2.7 \%$ and $4.7 \%$ of the average environmental impact generated by the eight functional mix scenarios of the DoE.

In the following, the three Significant Negotiable Functions are modeled as constraints and the three non significant are set at their nominal values.

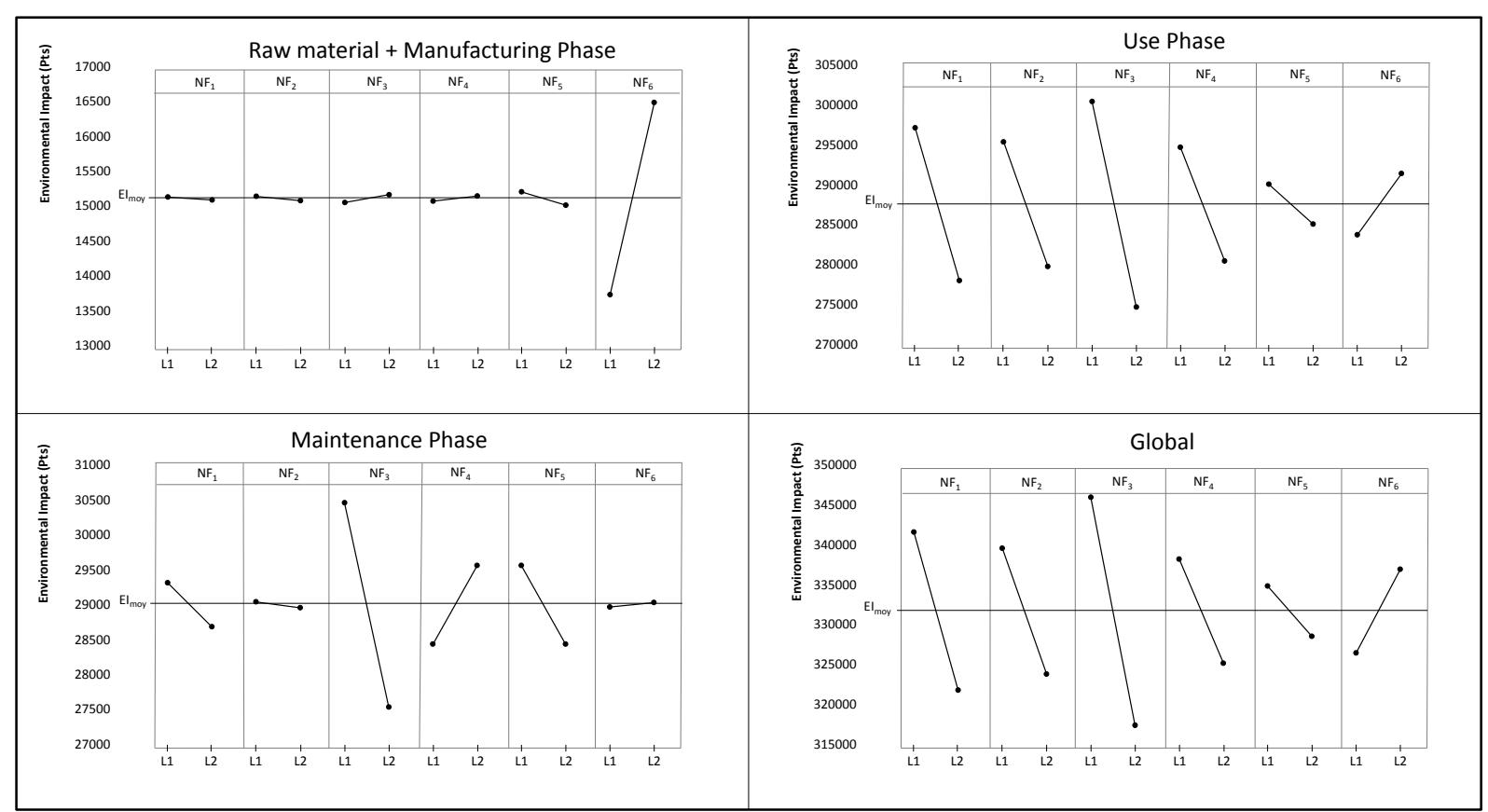

Figure 6 : Main effect of Negotiable Function on Environmental Impact.

\subsection{Optimisation of the systemfrom Significant Negotiable Functions (SNF)}

After an identification of the Significant Negotiable Functions, these functions are modeled as constraints:

- $\quad$ Maximum speed (kts) : $\mathrm{P}_{1}=[11.5,12]$.

- $\quad$ Passenger capacity per mission : $\mathrm{P} 2=\{97 ; 98 ; 99 ; 100\}$.

- $\quad$ Number of mission per day : $\mathrm{P} 3=\{23,24\}$.

The Functional Unit « Number of passengers transported per day » is also modeled as a constraint to satisfy $\mathrm{P}_{\mathrm{s}}=$ [2280, 2400].

Other "less significant" functions are set at their nominal values:

- No thermal insulation isolation thermique $\mathrm{P} 4$ nom $=\{0\}$.

- No Air Conditioning system P5 nom $=\{0\}$.

- Number of batteries chargesper day P6 $6_{\text {nom }}=\{1\}$.

The performance level of NF is identified by CSP.

The performance of three SNF to optimize the environmental performance of the system is characterized by a 11.5 knots as maximum speed, 98 passengers as a maximum capacity and 23 crossings per day (Table8). The main components of the system satisfying the requirements of functional mix globally optimized $\left(\mathrm{FM}_{\mathrm{GO}}\right)$ are defined Table9. The Functional Unit Globally Optimized $\left(\mathrm{FU}_{\mathrm{GO}}\right)$ is 2300 passengers per day. This corresponds to a reduction of about $5 \%$ of the nominal performance. However, in line with the trend observed on the effects of SNF (Figure 6), environmental impacts compared to the reference system are reduced by approximately $13 \%$. 


\begin{tabular}{|c|c|c|c|c|c|c|c|}
\hline & \multicolumn{7}{|c|}{ Parameters } \\
\hline $\begin{array}{l}\text { Functional } \\
\text { Mix }\end{array}$ & $\begin{array}{l}\text { P1: Maximal } \\
\text { Speed }\end{array}$ & $\begin{array}{l}\text { P2: Number of } \\
\text { passengers }\end{array}$ & $\begin{array}{l}\text { P3: Number } \\
\text { of missions }\end{array}$ & P4: isolation & $\begin{array}{l}\text { P5: } \\
\text { Climatisation }\end{array}$ & $\begin{array}{l}\text { P6 : Nombre } \\
\text { de charges }\end{array}$ & $\begin{array}{l}\text { Ps: Unité } \\
\text { fonctionnelle }\end{array}$ \\
\hline $\mathrm{FM}_{\mathrm{n}}$ & 12 & 100 & 24 & 0 (No insulation) & 0 (No AC) & 1 & 2400 \\
\hline $\mathrm{FM}_{\mathrm{go}}$ & 11.5 & 100 & 23 & 0 (No insulation) & 0 (No AC) & 1 & 2300 \\
\hline
\end{tabular}

Table9 : Specifications of main elements for system with $F M_{G O}$.

\begin{tabular}{|c|c|c|c|c|}
\hline & & $\begin{array}{c}\text { Functional } \\
\text { Mix normalized }\end{array}$ & $\begin{array}{c}\text { Functional Mix } \\
\text { globally } \\
\text { optimized }\end{array}$ & \\
\hline \multirow{2}{*}{ Engine } & Power & $80000 \mathrm{~W}$ & $70000 \mathrm{~W}$ & \\
\hline & Weight & $800 \mathrm{Kg}$ & $750 \mathrm{Kg}$ & \\
\hline \multirow{2}{*}{ Motor } & Power & $24000 \mathrm{~W}$ & $22000 \mathrm{~W}$ & \\
\hline & Weight & $94 \mathrm{Kg}$ & $85 \mathrm{Kg}$ & \\
\hline \multirow{2}{*}{ Generator } & Power & 10000 & 10000 & \\
\hline & Weight & 200 & 200 & \\
\hline \multirow{3}{*}{ Batteries } & Energy mission & $15 \mathrm{kWh} / 12,4$ & $15,2 \mathrm{Wh} / 12,6$ & \\
\hline & Weight & $501 \mathrm{Kg}$ & $460 \mathrm{Kg}$ & \\
\hline & Energy Density & $50 \mathrm{Wh} / \mathrm{Kg}$ & $50 \mathrm{Wh} / \mathrm{Kg}$ & \\
\hline \multirow[t]{2}{*}{ Hull } & Weight & $15000 \mathrm{Kg}$ & $15000 \mathrm{Kg}$ & \\
\hline & & & & gain \\
\hline \multirow{5}{*}{ Ship } & Impact of Use phase (Pts) & 292320 & 251160 & $-14,1$ \\
\hline & $\begin{array}{l}\text { Impact of Manufacturing } \\
\text { Phase (Pts) }\end{array}$ & 16325 & 16125 & $-1,2$ \\
\hline & \begin{tabular}{|l|}
$\begin{array}{l}\text { Impact of Maintenance } \\
\text { (Pts) }\end{array}$ \\
\end{tabular} & 27134,05 & 25250,78 & $-6,9$ \\
\hline & Global & 335779 & 292536 & $-12,9$ \\
\hline & Functional Unit & 2400 & 2300 & $-4,2$ \\
\hline
\end{tabular}

Reducing the system's performances or eliminating certain functions raises the question of outcomes for the passenger. For example, in this type of intercity transport, the number of passengers is not constant throughout the day. It fluctuates, and there are more people during rush hours. In the above simulations, the environmental gain is achieved to the detriment of « social » considerations; this is in contradiction to the concept of sustainable development. Reducing the amount of space on the ship results in constraints for the user. In parallel with initiatives to define a coherent functional mix (that we suggest with the EcoCSP tool), it is therefore necessary to set up measures to make sure that the system's ecological performances are not achieved at the expense of the users experience. This means, for example, setting up incentives to obtain a more regular flow of passengers throughout the day, such as preferential tariffs for certain time bands etc.

\subsection{Influence of the exhaustiveness of technological solutions on environmental performance.}

In this section, we propose to modify the component database "Engine". The database used to model the system comes from the manufacturers catalogs. In Figure 7 the speed of the nominal functional mix is reduced by $0.5 \mathrm{kts}$. In the first case the database "Engine" $\left(\mathrm{DB}_{0}\right)$ is not modified. In the second case, a new engine of $70 \mathrm{~kW}$ is added to the database $\left(\mathrm{DB}_{1}\right)$ (Figure 7). The integration of a $70 \mathrm{~kW}$ diesel engine in the component database of CSP model has allowed an environmental gain of $8 \%$ compared to the use of the initial database $\left(\mathrm{DB}_{0}\right)$ using diesel engines from manufacturers catalogs. More the alternatives are important more opportunities to generate better solutions for environment are high.

Functional negotiations must lead a questioning about the components to use in the system, which could otherwise limit the benefits of environmental performance. 


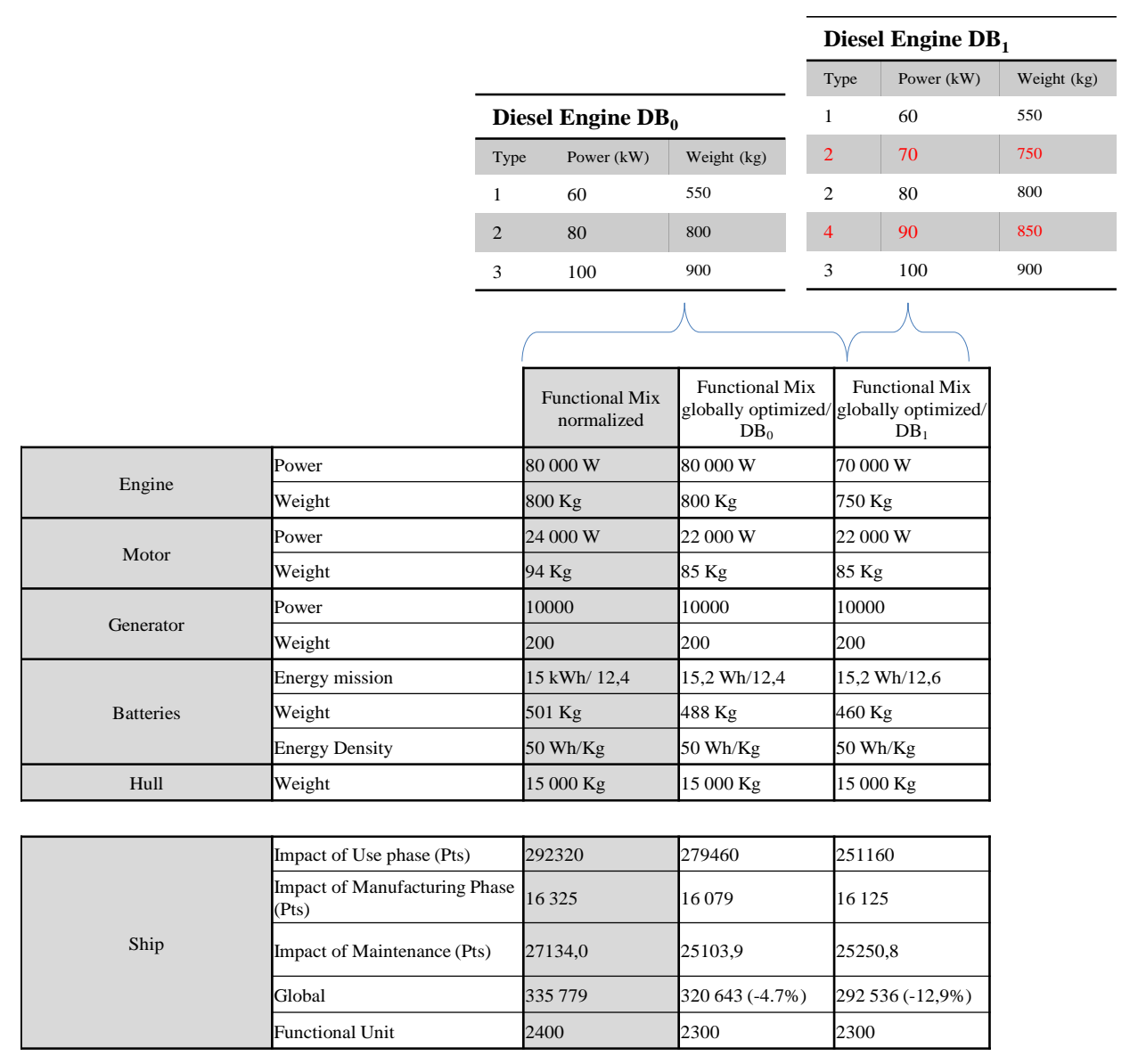

Figure 7 : Influence of Diesel Engine database on environmental performance

\section{Discussions and Conclusions}

The CSP / LCA approach relies on the CSP solver makes it possible to instantiate the design variables of the system that optimize the performance variables, in our case it is environmental criteria (but it could be also economic criteria). It allows to identify early in design process what are the best combinations of technologies, among many alternatives, for each subsystem whose functions are already specified in the specifications.

The Philosophy behind the use of CSP is to allow the designer to model and identify viable concepts reconciling environmental and economic aspects (CSP / LCA), but also the social aspects by acting on the definition of functional performance to get closer to a model of sustainable development.

In this article we have therefore enriched the CSP/LCA approach by constructing the EcoCSP approach. This enables us to anticipate the configuration of a system's architecture by adapting the performances of negotiable functions. A complex system such as a passenger ferry has numerous sub-functions. A slight downgrading of the performances related to these functions can generate substantial environmental gains. The complexity of couplings among sub-systems and their sheer number obliges the user to make use of «intelligent » tools, that by simulating many different scenarios, help the designer to fine-tune and choose the right technologies for sustainable systems.

This EcoCSP approach breaks with traditional design conventions, and allows us to define firstly combinations of technologies and secondly the functional mix that will significantly reduce environmental impacts. Life Cycle Analysis (LCA) is thus no longer used as a tool for system assessment and comparison, but as a tool for ecodesign.

In the experimentation phase we showed the significance of the number of alternatives suggested by the CSP model for reducing environmental impacts. The greater the number of alternative techniques, the higher the number of possibilities for generating better environmental solutions.

Finally, modifying the functional performances of a system results in new social, economic and environmental constraints. In parallel therefore, it is necessary to reflect on all the consequences of such modifications in order to avoid destabilizing the three mainstays of sustainable development. 
The EcoCSP tool allows us to make functional judgments and choices to optimize negotiable functional performances and thereby reduce environmental impacts. Nevertheless, this does not mean we should neglect consideration of the social consequences that these choices have on the system's use.

References

Abassard, C., and Agerri, F. 2002."La naissance de l'éco-conception : du cycle de vie du produit au management environnemental produit. Responsabilité et Environnement."

Ally, J., and Pryor, T. 2007."Life-cycle assessment of diesel, natural gas and hydrogen fuel cell bus transportation systems.". J Power Sources 170(2):401-411.

Ayeres, R. U., and Kneese, A.V. 1990."Externalities: Economy and Ecology: Towards sustainable development." In: Archibugi, F., Nijkamp, P. (eds) Dordrecht: Kluwer.

Baptista, P., Ribau, J., Bravo, J., Silva, C., Adcock, P., and Kells, A. 2011."Fuel cell hybrid taxi life cycle analysis." Energ Policy 39 (9): 4683-4691

Bartolozzi, I., Rizzi, F., and Frey, M. 2013."Comparison between hydrogen and electric vehicles by life cycle assessment: A case study in Tuscany, Italy." Appl Energ 101: 103-111.

Benhamou, F. 1995."Interval constraint logic programming. In: Podelski A (eds) Constraint Programming: Basics and Trends." Volume 910 of Lecture Notes in Computer Science, Springer-Verlag.

Benhamou, F., Goualard, F., Granvilliers, L., and Puget, J. F. 1999."Revising Hull and Box Consistency. In: De Schreye D (Eds.) Proceedings of International Conference on Logic Programming, Las Cruces, USA, The MIT Press.

Benhamou, F., and Older, W. J. 1997."Applying Interval Arithmetic to Real, Integer and Boolean Constraints."J Logic Program 32(1):1-24.

Boureima, F., Sergeant, N., Wynen, V., Rombaut, H., Matheys, J., Van Mierlo, J., De Vos, M., et al. 2008."LCA of conventional and alternative vehicles using a "data range-based modeling system"." Proceedings of Urban Transport XIV : Urban Transport and the Environment in the 21st Century:301-309.

Brezet, H., and van Hemel, C. 1997"EcoDesign: A promising approach to sustainable production and consumption, UNEP, France.

Castro, M. B. G., Remmerswaal, J. A. M., Reuter, M. A. 2003."Life cycle impact assessment of the average passenger vehicle in the Netherlands."Int J Life Cycle Assess 8(5):297-304.

Chenouard, R. 2007."Résolution par satisfaction de contraintes appliquée à l'aide à la décision en conception architecturale."Dissertation, ENSAM, Paris.

Chiriaev, D., and Walster, G. W. 1997."Interval arithmetic specification." Manuscript J3/97-199 for ANSI X3J3.

Cilliers, P. 1998. "Complexity and postmodernism: Understanding complex systems", London.

Daly, H. E. 1973."Towards a steady-state economy." San Francisco.

Debruyne, R., and Bessiere, C. 2001."Domain Filtering Consistencies." J Artif Intell Res 14:205-230.

Dewulf, W., Willems, B., and Duflou, J. R. 2005."Estimating the environmental profile of early design concepts for an electric fruit juicer using the Eco-Pas methodology." Life Cycle Engineering International Conference, Grenoble, France.

Ekvall, T., and Weidema, B. P. 2004."System boundaries and input data in consequential life cycle inventory analysis." Int J Life Cycle Assess 9(3):161-171

Finkbeiner, M., Hoffmann, R., Ruhland, K, Liebhart, D, and Stark, B. 2006."Application of Life Cycle Assessment for the Environmental Certificate of Mercedes-Benz S-Class." Int J Life Cycle Assess 11(4):240-246.

Freeman, C. 1992."The economics of hope: Essays on technical change, economic growth, and the environment." London.

Gao, L., and Winfield, Z. C. 2012."Life Cycle Assessment of Environmental and Economic Impacts of Advanced Vehicles." Energies 5(12):605-620.

Goedkoop, M., and Spreinsma, R. 2001."The Eco-indicator 99 - A damage oriented method for Life Cycle Impact Assessment - Methodology annex."Pré consultants.

Guinée, J. B., Gorrée, M., Heijungs, R., Huppes, G., et al. 2001. CML-Guide to Life Cycle Assessment. Institute of Environmental Sciences (CML), Leiden University, NL.

Hauschild, M., Jeswiet J., Alting, L. 2005."From Life Cycle Assessment to Sustainable Production: Status and Perspectives." Manuf Eng 3:1-21.

Herman, R., Ardekani, S., and Ausubel, J. 1989. In technology and environment. In: Ausubel J, Sladovich H (eds) Washington, DC, National Academy Press.

Hischier, R., and Reichart, I. 2003."Multifunctional Electronic Media - Traditional Media." Int J Life Cycle Assess 8(4):201-208 
Horvath, A. 2006."Environmental Assessment of Freight Transportation in the US." Int J Life Cycle Assess 11(4):229-239.

Hussain, M. M., Dincer, I., and Li, X. 2007."A preliminary life cycle assessment of PEM fuel cell powered automobiles." Appl Therm Eng 27(13): 2294-2299.

Ilog, IlogCP. 2006. Reference Manual, Ilog, Gentilly, France.

ISO 14040 (International Standard Organization. 2000."14040 series: environmental management - life cycle assessment - principles and framework."ISO 14040 series.

Jolliet, O., Saadé, M., Grettaz, P., and Shaked, S. 2005."Analyse du cycle de vie (ACV), Comprendre et réaliser un écobilan."Presses polytechniques et universitaires romandes.

Koffler, C., and Rohde-Brandenburger, K. 2009."On the calculation of fuel savings through lightweight design in automotive life cycle assessments."Int J Life Cycle Assess 15(1):128-135.

Krob, D. 2009."Eléments d'architecture des systèmes complexes, Gestion de la complexité et de l'information dans les grands systèmes critiques."CNRS Editions.

Lagerstedt, J. 2003."Functional And Evironmental Factors In Early Phases Of Product Development-Eco Functional Matrix." Dissertation, KTH, Stokholm.

Laudon, N., and Soriano, M. I. 2012."Comparative LCA of Electrified Heavy Vehicles in Urban Use." Master of Science Thesis in the Master's Degree Programme Technology, Society and the Environment.

Lee, J, Cho, H, Choi, B, Sung, J, Lee, S, and Shin, M. 2000."Life cycle assessment of tractors."Int J Life Cycle Assess 5(4): 205-208.

Levasseur, A. 2011."Développement d'une méthode d'analyse du cycle de vie dynamique pour l'évaluation des impacts sur le réchauffement climatique."Dissertation, Ecole polytechnique de Montréal.

Lhomme, O. 1993."Consistency Techniques for Numeric CSPs." Proceedings of IJCAI 93, Morgan Kaufmann, San Mateo, CA, USA.

Luttropp, C. 2005."Strategy and material flow in ecodesign." 12th CIRP international conference on Life Cycle Engineering, Grenoble, France.

Luttropp, C., and Lagerstedt, J. 2006."EcoDesign and The Ten Golden Rules: generic advice for merging environmental aspects into product development." J Clean Prod 14(15-16):1396-1408.

Ma, H., Balthasar, F., Tait, N., Riera-Palou, X., and Harrison, A. 2012."A new comparison between the life cycle greenhouse gas emissions of battery electric vehicles and internal combustion vehicles." Energ Policy 44:160-173.

Mackworth, A. K. 1977."Consistency in Networks of Relations." Artif Intell 8(1):99-118.

MacLean, H. L., and Lave, L. B. 2003. "Evaluating automobile fuel/propulsion system technologies." Prog Energ Combust29(1):1-69.

Mayyas, A. T., Qattawi, A., Mayyas, A. R., and Omar, M.A. 2012."Life cycle assessment-based selection for a sustainable lightweight body-in-white design."Energy 39(1):412-425.

Millet, D., Tchertchian, N., and Brissaud, D. 2009."How to identify the most promising areas of environmental improvement at the early stage of the design process." Int J Design Engineering 2(3):299-319.

Montanari, U. 1974."Networks of Constraints: Fundamental Properties and Applications to Picture Processing." Inform Science 7(2):95-132.

Moore, R. E. 1966."Interval Analysis." Prentice-Hall, Englewood Cliffs N.J.

Mousazadeh, H., Keyhani, A., Javadi, A., Mobli, H., Abrinia, K., and Sharifi, A. 2011."Life-cycle assessment of a Solar Assist Plug-in Hybrid electric Tractor (SAPHT) in comparison with a conventional tractor." Energ Convers Manage 52(3): 1700-1710.

Nagatomo, T., Miyauchi, T., and Tsuchiya, H. 1997. "Preliminary Investigation for Life Cycle Assessment (LCA) of Shinkansen Vehicles", http://www.rtri.or.jp/infoce/wcrr97/E142/E142.html accessed on 10 June 2003.

Nanaki, E. A., and Koroneos, C. J. 2012."Comparative LCA of the use of biodiesel, diesel and gasoline for transportation." J Clean Prod 20(1):14-19.

Owens, J. W. 1997."Life-cycle assessment in relation to risk assessment: an evolving perspective." Risk Anal 17(3):359-365.

Pehnt, M. 2002."Life Cycle Assessment of Fuel Cell Systems." Erscheint in Fuel Cell Handbook, 3.

Potting, J., and Hauschild, M.Z. 2006."Spatial differentiation in life cycle impact assessment: a decade of method development to increase the environmental realism of LCIA." Int J Life Cycle Assess 11:1113.

Querini, F., Dagostino, S., Morel, S., and Rousseaux, P. 2012."Greenhouse Gas Emissions of Electric Vehicles Associated with Wind and Photovoltaic Electricity." Energy Procedia 20: 391-401.

Reap, J., Roman, F., Duncan, S., and Bras, B. 2008."A survey of unresolved problems in life cycle assessment." Int J Life Cycle Assess 13(5): 374-388 
Schmidt, W. P., Dahlqvist, E., Finkbeiner, M., Krinke, S., Lazzari, S., Oschmann, D., Pichon, S., et al. 2004 "Life Cycle Assessment of Lightweight and End-of-Life Scenarios for Generic Compact Class." Int J Life Cycle Assess 9(6): 405-416.

Schwab Castella, P., Blanc I., Gomez Ferrer, M., Ecabert, B., Wakeman, M., Manson, J. A., Emery, D., et al. 2009."Integrating life cycle costs and environmental impacts of composite rail car-bodies for a Korean train." Int J Life Cycle Assess 14(5):429-442.

Schweimer, G. W., and Levin, M. 2000."Life Cycle Inventory for the Golf A4." Research, Environment and Transport, Volkswagen AG, Wolfsburg, Germany.

Simonis, U.E., 1985. Preventative environmental policy: Prerequisites, trends and prospects. Ekistic 313:369372.

Spielmann, M., Scholz, R., Tietje, O., and Haan, P. 2005."Scenario Modelling in Prospective LCA of Transport Systems. Application of Formative Scenario Analysis." Int J Life Cycle Assess 10(5):325-335.

Spielmann, M., De Haan, P., and Scholz, R.W. 2008."Environmental rebound effects of high-speed transport technologies: a case study of climate change rebound effects of a future underground maglev train system." J Clean Prod 16(13):1388-1398.

Strazza, C., Del Borghi, A., Costamagna, P., Traverso, A., and Santin, M. 2010."Comparative LCA of methanolfuelled SOFCs as auxiliary power systems on-board ships." Appl Energ 87(5):1670-1678.

Subic, A., and Schiavone, F. 2010."Comparative Life Cycle Assessment (LCA) of passenger seats and their impact on different vehicle models." Int J Vehicle Des 53(1-2):89-109.

Sweeting, W.J., and Winfield, P.H. 2012."Future transportation: Lifetime considerations and framework for sustainability assessment." Energ Policy 51:927-938.

Taguchi, G., Elsayed, E. and Hsiang, T. 1989."Quality Engineering In Production System", New York McGraw Hill.

Takeda, K., Sugioka, S., and Shimada, Y. (2008) LCA of the Various Vehicles in Environment and Safety Aspect. ; Proceedings of the 12th international conference on Knowledge-Based Intelligent Information and Engineering Systems, Pt 3, 9-16.

Tchertchian, N., Yvars, P. A., and Millet, D. 2013."Benefits and limits of a Constraint Satisfaction Problem/Life Cycle Assessment approach for the ecodesign of complex systems: a case applied to a hybrid passenger ferry." J Clean Prod 42:1-18.

Tharumarajah, A., and Koltun, P. 2007."Is there an environmental advantage of using magnesium components for light-weighting cars?" J Clean Prod 15(11-12):1007-1013.

Tillman, A. M. 2000."Significance of decision-making for LCA methodology." Environ Impact Asses 20:113123.

Van den Hoed, R.1997."An exploration of approaches towards Sustainable Innovation and their implications on the product development process", Proceedings of The Greening of Industry Conference Developing Sustainability: New Dialogue, New Approaches.

Van Mierlo, J., Maggetto, G., and Lataire, P.2006."Which energy source for road transport in the future? A comparison of battery, hybrid and fuel cell vehicles." Energ Convers Manage 47(17):2748-2760.

Van Weenen, J. C.1995."Towards sustainable product development." J Clean Prod 3(1-2):95-100.

Von Weizsäcker, E., Hargroves, K., Smith, M. H., Desha, C., and Stasinopoulos, P. 2009."Factor Five. Transforming the Global Economy through 80\% Improvements in Resource Productivity." Earthscan, London.

Wagner, U., Eckl, R., and Tzscheutschler, P. 2006."Energetic life cycle assessment of fuel cell powertrain systems and alternative fuels in Germany." Energy 31(14):3062-3075.

Weidema, B. P. 2003."Market Information in Life Cycle Assessment." In: Environmental Project No. 863. Danish Environmental Protection Agency, Copenhagen.

William, R. E., Larson. E.D., and Ross, M. H. 1987."Materials, Affluence, and Industrial Energy Use." Annu Rev Energy 12:99-144.

Wimmer, W., and Züst, R.2003."ECODESIGN Pilot, Product-Investigation-, Learning- and Optimization-Tool for Sustainable Product Development." Alliance for Global Sustainability Bookseries.

Zackrisson, M., Avellán L., and Orlenius, J. 2010."Life cycle assessment of lithium-ion batteries for plug-in hybrid electric vehicles - Critical issues." J Clean Prod 18(15):1519-1529.

Zamel, N., and Li, X. 2006."Life cycle comparison of fuel cell vehicles and internal combustion engine vehicles for Canada and the United States." J Power Sources 162(2):1241-1253.

Annex: Results of the multi-criteria environmental assement 
Table: Multicriteria assessment according CML Method ${ }^{I}$.

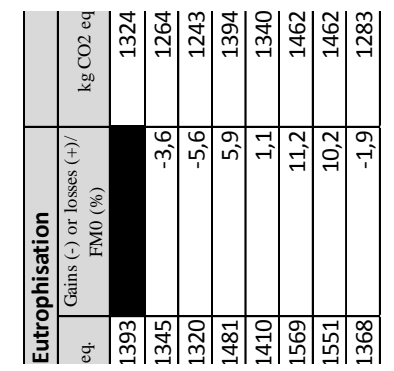

${ }^{1}$ Guinée, J.B., Gorrée, M., Heijungs, R., Huppes, G., et al. 2001. "CML-Guide to Life Cycle Assessment." Institute of Environmental Sciences (CML), Leiden University, NL 